\title{
UNDERGROUND FLOW STUDY OF GREAT CAUCASIAN RIVERS WITHIN AZERBAIJAN
}

\author{
Farda Imanov $\bowtie$, Irada Aliyeva \\ Department of Hydrometeorology, Faculty of Geography, Baku State University, Zahid Khalilov street, 23, AZ 1148, Baku, Republic \\ of Azerbaijan
}

\begin{abstract}
Aim of the study

The use of underground water for drinking water supply has increased over the recent years, due to intensive pollution of local and transboundary rivers in the Greater Caucasus region of Azerbaijan. In addition to relatively deep groundwaters, underground flow of rivers is also widely used for the purpose. The purpose of the present study is to analyze the condition of underground flow of rivers in the region, and to determine their territorial distribution patterns.
\end{abstract}

\begin{abstract}
Material and methods
The possibilities of using the minimum monthly water discharge have been investigated to determine the annual rates of underground flow to rivers. The study was conducted in 4 options, and in each option the values obtained based on the minimum monthly discharge of underground flow have been compared to values obtained based on hydrographs separation drawn up for typical years.
\end{abstract}

\begin{abstract}
Results and conclusions
The underground flow coefficient, which is a quantitative indication of the recharge of groundwaters by infiltration in the Greater Caucasus region, is affected by the physical and geographical factors. As the average altitude increases, the underground flow coefficient also increases. Thus, the average altitude of catchment area is an integral indicator of the physical and geographical factors affecting the recharge of groundwaters by infiltration. The difference between the average multi-year values of the Greater Caucasus rivers baseflow coefficient and the coefficient of recharge by groundwater is about 0.25 . In the area under investigation, the coefficient of recharge by groundwater for the studied rivers is on average $63.85 \%$ in dry years, $55.2 \%$ in medium years, and $59.5 \%$ in wet years.
\end{abstract}

Keywords: infiltration, underground water, Greater Caucasus, hydrograph separation, minimum flow

\section{INTRODUCTION}

Only $36 \%$ of the atmospheric precipitation falling on the dry ground surface generates streamflow (Ward \& Robinson, 2000). It is known that, regardless of the river's size, each streamflow has two primary sources: overland flow (surface run-off) and underground flow (baseflow). $30 \%\left(12,500 \mathrm{~km}^{3}\right)$ of overall annual streamflow of the Earth's rivers comes from groundwaters (Lvovic, 1986). It is also important to note that underground waters have a particularly significant role in the regime of rivers during the low-flow period.

Azerbaijan has limited surface water resources, of which $70 \%$ are from transboundary rivers. Upon entering the country's area, these rivers are already mostly contaminated. Therefore, in Azerbaijan, including the

凶e-mail:farda_imanov@mail.ru 
Greater Caucasus region, underflow waters of local rivers are widely used along with spring and deep-well waters. In central cities of 12 administrative regions (out of 65 country total), spring and deep-well waters are the sources of drinking water. The productivity of water intake facilities built on river channels ranges from 30 to $2201 / \mathrm{sec}$.

In large river basins, the atmospheric precipitation is distributed unequally and the runoff period of surface waters is high. The flood waves of large river branches undergo transformation along the river and therefore are weakly noticeable in the main river hydrograph or are not visible at all. Therefore, while dividing river hydrographs by feeding sources, the overland flow formed in its arms is referred to as the underground stream of the main river. For this reason, this article considers the mechanism of formation of underground flow in small rivers or source of the large rivers.

The surface and underground flow quantity and ratio vary depending on the features of the basin, such as soil type, vegetation cover, amount of atmospheric precipitation, and its annual distribution. Groundwaters are classified as follows by the level of feeding the rivers: fast underflow; underflow; upper underground flow; deep underground flow; and historical underground flows (Vinogradov and Vinogradova, 2008). Generally, deep groundwater is determined by multiyear minimum water discharge.

Detailed information on river flow sources is given in various reports: channel precipitation (Rawitz et al., 1970); surface runoff (Abrahams et al., 1994; Anderson and Spencer, 1991); the flow of groundwater close to ground surface (Bonell et al., 1984; Jungerius, 1985).

It should be noted that all these components of the overall streamflow can only be estimated by individual experimental studies. In practice, it is sufficient to assess only the two main components of the flow overland and underground flow - in order to estimate and forecast the streamflow features.

The response of overall streamflow to the atmospheric precipitation (specific rainfall, seasonal and annual precipitation) depends on the physical and geographical condition of the area and the role of streamflow sources. Part of the precipitation falling on the catchment surface reaches the surface of the groundwater by silting through the rocks, increases their re- serve, and is discharged from the saturated zone into the main river channel as an underground stream.

Typically, because water is moving too slowly within the rock layers, groundwaters reach to the river bed within several days, weeks, or even years following the fall of atmospheric precipitation. In areas where the coralized and cracked rocks are spread, groundwaters have a faster response to atmospheric precipitation.

R. E. Horton and J.D. Hewlett played a particularly important role in studying flow processes.

Horton's theory (Horton, 1933) is known as a theory of infiltration in the post-Soviet countries. According to Horton, a part of rainwater falling on the ground surface generates surface runoff toward riverbeds. The remaining part of the rainwater generates underground flow by moving to the soil-rock layer, or is consumed for evaporation.

The proportion between these two main parts of the rainwater depends on the soil's infiltration capacity - the maximum amount of rainwater that can be absorbed. If the intensity of the rainfall is higher than the dry soil capacity to absorb the rainwater, the extreme rainfall generates overland flow. Otherwise, the surface runoff is not generated. If the infiltration process continues after the water moved down underground has reached groundwater surface, the groundwater flow to the riverbed begins to increase. According to Horton's theory, the volume of infiltration varies in each rainfall as per general regularity. In essence, at the beginning of the rainfall, the amount of infiltration is maximum, and after that, it rapidly weakens.

In subsequent studies carried out in various countries, the overall form of infiltration curve put forward by Horton has been confirmed; however it has been established that several factors (change of hydraulic conductivity and initial moisture gradient depth, length of the moving distance of waters) within the soil profile impact the reduction speed of infiltration.

Influence of infiltration amount on streamflow can be summarized as follows: extreme intensity rainfall can cause surface runoff on the entire surface of the river basin; moderate intensity rains can only generate overland flow after a sharp decrease in infiltration amount; low-intensity rains are not able to generate overland flow.

Unlike Horton's theory, information about Hewlett's theory (Hewlett, 1961; Hewlett and Hibbert, 
1967) is almost not available in scientific literature published in the post-Soviet countries. According to Hewlett, even in intensive and persistent rains, all of the rainwater is infiltrated in most of the basin surface. Infiltrated underground waters located close to the surface within the soil profile cause the level of water to rise to the surface of the ground in saturated zones. This process is primarily observed in the areas where groundwaters are closer to the surface and the riverbed, then gradually moving to the rest of the valley slopes.

When the upper boundary of the saturated zone reaches the surface of the ground, the volume of infiltration equals zero, regardless of the rainfall intensity in the area, and the rainwater generates only overland flow. Thus, according to Horton's theory, overland flow is generated when the intensity of rainfall exceeds the intensity of infiltration. In contrast, according to Hewlett's theory, it occurs when the upper boundary of the saturated zone reaches the ground surface. In other words, according to Hewlett, the rainfall falling to the rest of the river basin is absorbed. The process of overland flow generation in Horton's theory can be regarded as a particular case of Hewlett's theory (Ward and Robinson, 2000).

Underground and surface waters are interconnected, which occurs through water exchange between underground waters and waters of oceans, seas, lakes, swamps and rivers. Most of the underground water flows into the oceans and inland seas through rivers, while a small proportion flows directly into the oceans, seas and lakes. The central part of both surface and underground waters is interconnected via a global watercourse, while the rest via inland watercourse. The heat and water-soluble substance exchange occur within the process between the two considered types of waters - underground and surface waters.

The general territorial distribution of underground flows corresponds to the distribution of atmospheric precipitation and streamflow, that is, it depends on the climate and physical-geographical and geological features of the basin. The highest value of the underground flow is recorded in dense rainfall areas, and the lowest, in dry regions.

The interaction between underground and surface waters is of different nature, and it depends on the features of the underlying bed, the degree of the riverbeds and valleys deepening in the underlying bed, the density of the hydrographic network, and the location of the surface to which the underground waters seeped out relative to the level of river waters. Hydraulic interaction between groundwater and river water is dependent on the latter factor. Sometimes the nature of the interaction between underground and surface waters varies depending on the phases of the river regime: during the low-water period no hydraulic interaction occurs, while during the high-water and flood period hydraulic interaction occurs. The nature of hydraulic interaction between surface and underground waters also varies along the river. For example, different types of interaction may occur in upstream and downstream flows of mountain rivers (Doganovskiy and Malinin, 2004).

The main objective of the article is to identify patterns of distribution of the underground runoff in the rivers of the Greater Caucasus, taking into account the main physical and geographical factors, and to develop a method for determining the annual values of this component of the total river runoff without separating river hydrographs.

\section{MATERIALS AND METHODS}

The Greater Caucasus region covers the northern part of Azerbaijan and extends from the Caspian Sea to the border with Georgia (see: Fig. 1). It covers the area of $40,603 \mathrm{~km}^{2}$ where the absolute altitudes vary from $-27 \mathrm{~m}$ to $4466 \mathrm{~m}$. Most of the region's area is the Main Caucasus Range. The lateral ridges run parallel to the Main Caucasus Range. The region features several plains, which are Gusar plain, Ganikh-Ayrichay plain, and Shirvan plain.

The Greater Caucasus region has a complex geological structure. In altimontane and mid-montane zones, limestone, sandstone, clay slates and clays of Mesozoic era, Jurassic and Cretaceous period are commonly occurring. In lower montane zones, the Paleogene and Neogene deposits of Cenozoic era are common, along with rocks of the Cretaceous period. Quaternary deposits form thick coatings are found in submontane zones (foothill plains).

The region is one of the most seismically active areas of Azerbaijan. Most of the country's mudflow rivers are flowing through this region. 


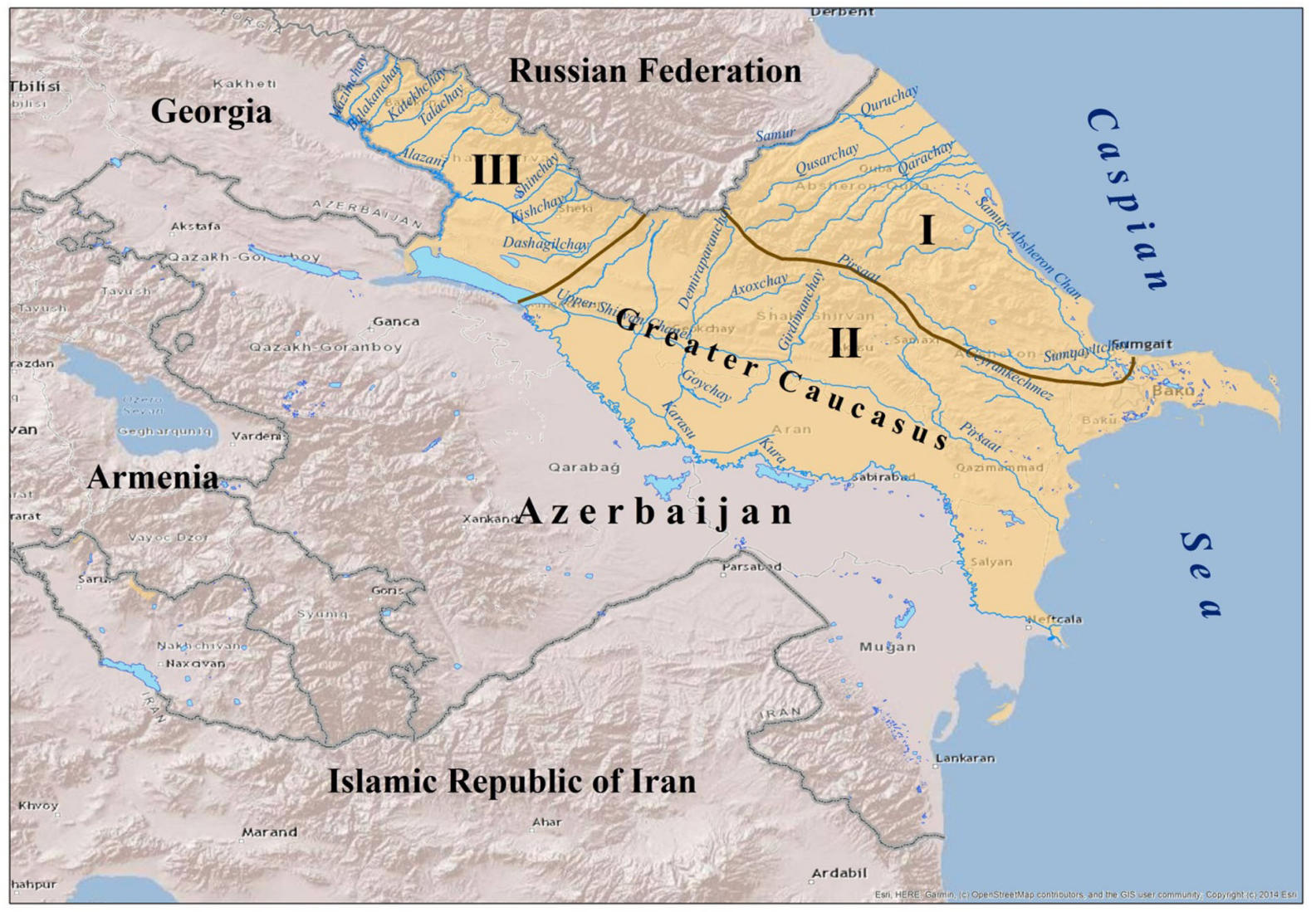

Fig. 1. Hydrological map of the study area. Source: own study

The Greater Caucasus is rich in fossils and mineral water sources, including oil, natural gas, polymetallic and copper ores, as well as limestone, marble, clay and other construction materials.

The climate of the region is diverse, changing from semi-desert and dry-desert to mountain-tundra climate types. While the average January temperature of the region is below $0^{\circ} \mathrm{C}$ in the plains, the temperature falls to $-5^{\circ} \mathrm{C}$ at the height of $2,000 \mathrm{~m}$, and up to $-10^{\circ} \mathrm{C}$ at $3,000 \mathrm{~m}$. The amount of annual precipitation varies from 250 to $1700 \mathrm{~mm}$.

The river network in the Greater Caucasus is denser than in other regions of Azerbaijan. The rivers fall into the Kura River or directly into the Caspian Sea; in most of them, intense floods occur frequently. There are many small lakes of diverse origin (glacial, tectonic, relict) in the Greater Caucasus region. The river waters are widely used for irrigation. Many reservoirs are installed on rivers.
Normal annual precipitation of the region is $399 \mathrm{~mm}$, while evaporation is $265 \mathrm{~mm}$ and total streamflow is $134 \mathrm{~mm}(81 \mathrm{~mm}$ overland and $53 \mathrm{~mm}$ underground flow) (Rustamov and Kashkay, 1978).

In the Greater Caucasus Mountains, soil-vegetation varies by altitudinal belts. Gray and grey-brown soils are predominant in plain areas, cinnamon-brown and brown soils in foothills, mountain-black and brown mountain-forest soil types in mountainous areas.

The forest landscape appears mainly between the altitudes of $500-600 \mathrm{~m}$ and $1,800-2,000 \mathrm{~m}$ in the region (sometimes small forest areas are found at 2,200 $\mathrm{m}$ and above). Oak, hornbeam, hazelnut trees are prevalent in mountain forests. The forests also appear in the plains where groundwater is close to the surface.

Mountain-meadow landscapes (subalpine and alpine meadows) spread above the mountain forests $(2,000-3,000 \mathrm{~m})$. Nival landscape is formed above 
$3,000 \mathrm{~m}$. The snow line, above which snow and glaciers dominate, is $3,900 \mathrm{~m}$.

The input material for this study consisted of the data from hydrological observations (1934-2017) at 30 observation points, the information contained in various statistical handbooks, and literature data. The main research method was a geo-hydrological synthesis of statistical data contained in the source materials. Within the framework of this methodology, the separation of river hydrographs was performed, homogeneous hydrological regions were identified, empirical correlations of runoff and its main factors were constructed, and statistical tests were applied.

\section{RESULTS AND DISCUSSION}

Only a small portion of atmospheric precipitation is consumed for the generation of underground waters. In the south of the European part of Russia, the infiltration accounts for a maximum of $20 \%$ of the annual precipitation, in the northern part of Paramushir Island (Kuril Islands) it is about $13 \%$ (Kalacheva, 2008), in Armenia it ranks around $15 \%$ in areas above $3,300 \mathrm{~m}$ and $25 \%$ at the altitude of 1,500-2,800 $\mathrm{m}$ (Sokolov and Sarkisyan, 1981). When the annual rainfall is below $130-250 \mathrm{~mm}$, natural recharge of groundwaters stops in the areas where high water permeability soils are not found.

The quantitative indicators of groundwater supply by infiltration vary greatly depending on the landscape and soil types, as well as the geological structure of the area. These differences are mostly dependent on the landscape type of the basin. Compared with these factors, the role of meteorological climate is relatively marginal. The Moscow Artesian Basin sample showed that feeding by infiltration varies between 60 and $100 \mathrm{~mm} /$ year depending on the meteorological conditions. However, because landscape types, soil cover and geological structure are not uniform, the values vary at more significant intervals $(0-160 \mathrm{~mm} /$ year). Average annual rates of both absolute and relative quantities of recharge by infiltration (share in annual precipitation and annual flow) increase when the amount of rainfall increases and average annual temperature decreases. The maximum values of infiltrated waters are typical of forest landscape with sandy soils, whereas minimal values are typical of open fields with clayey soil (Grinevskiy and Novoselova, 2010). This is confirmed by the observa- tion data obtained during experimental studies. According to these reports, approximately $80 \%$ of snowfall and fluid rainfall do not generate surface runoff during the high-water period in the forest landscape (Hydrological..., 1989; Subbotin, 1966).

In all three hydrological regions of the Greater Caucasus (see: Fig. 1), the influence of the forest cover coefficient (FCC) and the average altitude (AA) of the river catchment areas on underground flow coefficient (UFC), including the relative and absolute rates of underground flows were considered. In Ganikh basin (region III), around $35 \%$ of the annual rainfall is consumed for the generation of groundwaters. In contrast, in the north-eastern slope (region I) it is $24 \%$, and in the Shirvan region (region II), 19\%. The figure varies between 0.05 (Davachichay) and -0.46 (Damarjik River) in the Greater Caucasus region.

It has been established that only in region I there is a robust reverse relationship between the UFC, as well as the absolute value of underground flow and the FCC of the river catchment areas. The correlation coefficients of these relationships are -0.76 and -0.77 , respectively. Figure 2 illustrates the relationship between the UFC and the FCC of the river catchment areas. As it is apparent from Figure 2, the UFC decreases when the FCC of the catchment areas increases. The stated correlation was not revealed in the other two regions.

In the regions I and III, the coefficient of recharge by underground waters (GFC) also decreases with the increase of the FCC. The correlation coefficients of these relationships are -0.72 and -0.75 , respectively. The stated correlation was not observed in region II.

Unlike the relationships mentioned above, in all three regions, there is a robust relationship between the UFC and the AA of the catchment area. The correlation coefficients of these relationships are $0.79,0.89$ and 0.96 , respectively. According to t-Student test, all these correlation coefficients are statistically significant at $p=0.10$. As the AA increases, the UFC also increases. Figure 3 illustrates the stated relationship for Shirvan region.

The study of these relationships shows that the AA of the catchment area is the integral indicator of physical and geographical factors (meteo-climatic conditions, landscape and soil types, geological structure) that affect the feeding of groundwaters by infiltration.

The GFC is used to estimate the role of groundwater in runoff generation. This ratio is also a quantitative in- 
dicator of interaction between surface and underground waters. For the majority of mountain rivers, this ratio varies between 40-60\% (Water Resources of Russia, 2008).

The runoff generation conditions, its different features (annual, maximal, minimal flow, etc.) and the proportion of these features vary depending on altitudes in mountainous areas. Therefore, the groundwater recharge coefficients for Greater Caucasus rivers were calculated (see: Table 1) and their dependence on altitudes was considered.

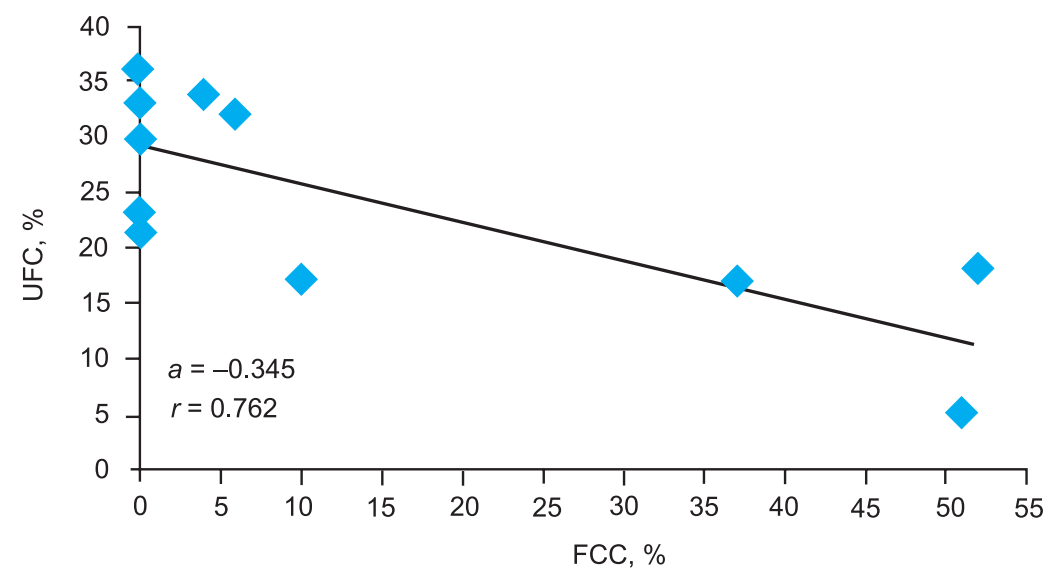

Fig. 2. The relationship between the underground flow coefficient and the forest cover coefficient (region I).

Table 1. Groundwater recharge coefficient of rivers, $\%$.

\begin{tabular}{|c|c|c|c|c|}
\hline № & River & Gauging station & $\begin{array}{c}\text { Groundwater recharge } \\
\text { coefficient, } \%\end{array}$ & $\begin{array}{l}\text { Average altitude of the } \\
\text { watershed, } m\end{array}$ \\
\hline 1 & Gusarchay & Kuzun & 40 & 2940 \\
\hline 2 & Guruchay & Susay & 41 & 1930 \\
\hline 3 & Gudyalchay & Q1r1z & 44 & 2590 \\
\hline 4 & Gudyalchay & Kupchal & 46 & 2400 \\
\hline 5 & Gudyalchay & Khinalig & 38 & 2780 \\
\hline 6 & Garachay & Ruk & 53 & 2600 \\
\hline 7 & Cagacukchay & Rustov & 33 & 1450 \\
\hline 8 & Valvalachay & Tangaalti & 38 & 1870 \\
\hline 9 & Xarmidorchay & Xaltan & 36 & 1380 \\
\hline 10 & Balakanchay & Balakan & 46 & 1560 \\
\hline 11 & Talachay & Zagatala & 46 & 1710 \\
\hline 12 & Ayrichay & Bash Dasag1l & 48 & 1560 \\
\hline 13 & Damarciq & Close to estuary (Kish) & 50 & 1860 \\
\hline 14 & Alincanchay & Gayabashi & 43 & 990 \\
\hline 15 & Demiraparanchay & Gabala (Gutqashen) & 38 & 2430 \\
\hline 16 & Axoxchay & Xanagah & 38 & 1660 \\
\hline 17 & Goychay & Goychay & 42 & 970 \\
\hline 18 & Girdimanchay & Garanohur & 39 & 1820 \\
\hline 19 & Pirsaat & Poladl1 & 37 & 1000 \\
\hline
\end{tabular}




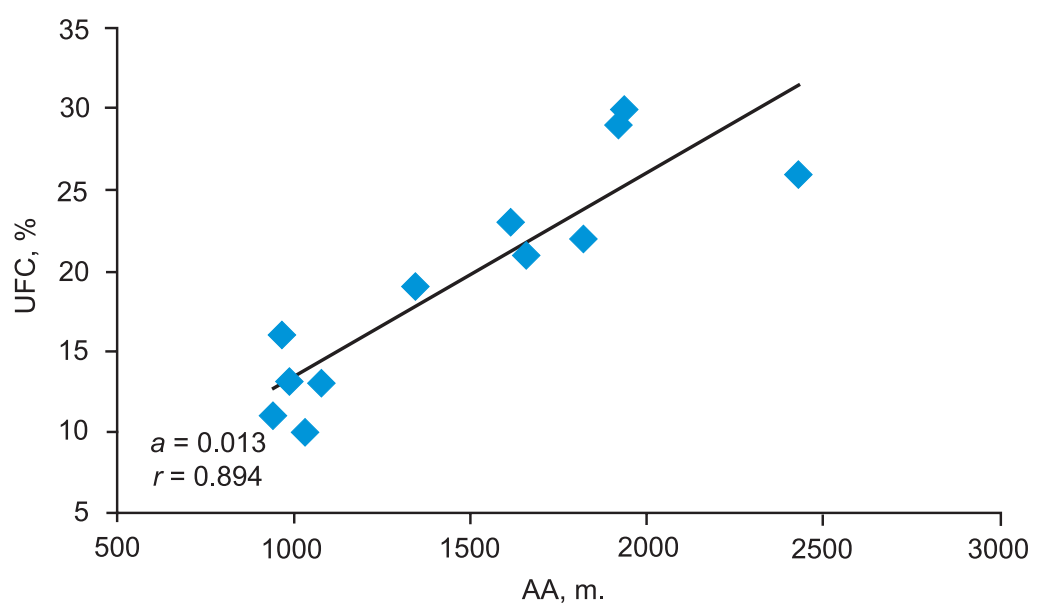

Fig. 3. The relationship between the underground flow coefficient and the average altitude of the watershed (region II)

Certain regularity was found only for the rivers of northeastern slopes of Greater Caucasus (see: Fig. 3). As shown in the figure, the GFC increases when the AA of the catchment areas increases. However, the increase continues up to 2,600 $\mathrm{m}$ altitude, and the GFC begins to decrease in higher altitudes. The similar studies were carried out previously for other mountainous regions of Azerbaijan. In essence, the north-eastern slope of the Small Caucasus and in Karabagh rivers found that the GFC decreases above 2,300-2,400 $\mathrm{m}$ (Imanov and Alakbarov, 2014). This can be explained by the long-term winter period in high mountain regions, freezing of the soil layer and, as a consequence, the decline in groundwater flow to the rivers. It should be noted that the minimum winter flow of Avar-Koysu and Andi-Koysu River Basins (Dagestan Republic, Russian Federation), fed only by underground water during the low-water winter period, begins to decline above the altitude of approximately 2,700 $\mathrm{m}$ (Imanov, 2000).

No similar correlations have been found for other two districts - Shirvan hydrological district (region II) or Ganikh basin (region II), which may be due to two fundamental reasons mentioned below:

1. Lack of information on GFC in these regions (only 6 stations in Shirvan and 4 stations in Ganikh basin);

2. A low value of change interval of GFC in the regions. For example, the GFC varies between $37-43 \%$ in Shirvan hydrological region (on average, $40 \%$ ) and $46-50 \%$ in Ganikh basin (on average, $48 \%$ ).
For the sake of comparison, it should be noted that the ratio of the coefficient for region I ( 9 hydrological monitoring stations) varies in a larger interval (33$53 \%$ i.e. by $41 \%$ on average).

Additionally, hydrographs were drawn up based on data of different water years for 8 rivers, and surface runoff and underground flow was estimated (see: Table 2). The dry, medium and wet years have been selected based on annual runoff rates of 75, 50 and $25 \%$. It has been established that the GFC for the rivers in dry years is $63.85 \%$ on average, $55.2 \%$ in medium years, and $59.5 \%$ in wet years. The results of this evaluation once again confirm that the role of groundwater in feeding rivers increases during low-water years.

The amounts of overland and underground flows, as well as their proportions, were analyzed based on the data from 1961 (extremely dry year) and 2010 (extremely wet year) distinguished by extreme hydrological conditions (see: Table 3). During the drought of 1961 , the annual rainfall amounted to $50 \%$ of the norm, whereas during the high water of 2010 , the annual rainfall exceeded the norm by $11.4 \%$ (Imanov et al., 2015).

It has been established that the groundwater recharge coefficient was $49.9 \%$ for rivers in extreme low-water year of 1961, and $68.9 \%$ in extreme high-water year of 2010. The outcomes of this assessment do not support the idea of increasing the role of groundwaters in feeding rivers during dry years. Apparently, during rarely 
Imanov, F., Aliyeva, I. (2020). Underground flow study of Great Caucasian rivers within Azerbaijan. Acta Sci. Pol., Formatio Circumiectus, 19 (1), 61-72. DOI: http://dx.doi.org/10.15576/ASP.FC/2020.19.1.61

Table 2. Surface and underground flows of rivers for various years.

\begin{tabular}{|c|c|c|c|c|c|c|c|c|}
\hline \multirow{2}{*}{ № } & \multirow{2}{*}{ River-gauging station } & \multirow{2}{*}{ Years } & \multirow{2}{*}{$\begin{array}{c}\text { Average } \\
\text { annual water } \\
\text { discharge, } \mathrm{m}^{3} / \mathrm{s}\end{array}$} & \multirow{2}{*}{$\begin{array}{l}\text { Annual flow, } \\
\text { million } \mathrm{m}^{3}\end{array}$} & \multicolumn{2}{|c|}{ Underground flow } & \multicolumn{2}{|c|}{ Surface flow } \\
\hline & & & & & million $\mathrm{m}^{3}$ & $\%$ & million $\mathrm{m}^{3}$ & $\%$ \\
\hline \multirow{3}{*}{1} & \multirow{3}{*}{ Gusarchay-Kuzun } & 1953 & 3.20 & 101 & 52.3 & 51.8 & 48.7 & 48.2 \\
\hline & & 1952 & 4.74 & 150 & 83.2 & 55.5 & 66.8 & 44.5 \\
\hline & & 1967 & 7.32 & 231 & 94.0 & 40.7 & 137 & 59.3 \\
\hline \multirow{3}{*}{2} & \multirow{3}{*}{ Valvalachay-Tangaalti } & 1947 & 2.52 & 79.5 & 53.0 & 66.7 & 26.5 & 33.3 \\
\hline & & 1968 & 4.20 & 133 & 79.8 & 60.0 & 53.2 & 40.0 \\
\hline & & 1966 & 7.32 & 231 & 217 & 93.9 & 14 & 6.10 \\
\hline \multirow{3}{*}{3} & \multirow{3}{*}{ Shabranchay-Zeyva } & 1965 & 0.13 & 4.10 & 2.70 & 65.9 & 1.40 & 34.1 \\
\hline & & 1968 & 0.32 & 10.1 & 5.3 & 52.5 & 4.8 & 47.5 \\
\hline & & 1967 & 1.27 & 40.1 & 15.2 & 37.9 & 24.9 & 62.1 \\
\hline \multirow{3}{*}{4} & \multirow{3}{*}{ Girdimanchay-Garanohur } & 1971 & 3.86 & 122 & 80.3 & 65.8 & 41.7 & 34.2 \\
\hline & & 1972 & 6.88 & 217 & 108 & 49.8 & 109 & 50.2 \\
\hline & & 1967 & 9.24 & 292 & 168 & 57.5 & 124 & 42.5 \\
\hline \multirow{3}{*}{5} & \multirow{3}{*}{ Goychay-Buynuz } & 1953 & 5.79 & 183 & 144 & 78.7 & 39 & 21.3 \\
\hline & & 1962 & 8.97 & 283 & 150 & 53.0 & 133 & 47.0 \\
\hline & & 1959 & 11.7 & 369 & 315 & 85.4 & 54 & 14.6 \\
\hline \multirow{3}{*}{6} & \multirow{3}{*}{ Ayrichay-Bash-Dashagil } & 1953 & 1.41 & 44.5 & 28.8 & 64.7 & 15.7 & 35.3 \\
\hline & & 1969 & 2.96 & 93.4 & 53.2 & 57.0 & 40.2 & 43.0 \\
\hline & & 1963 & 5.70 & 180 & 120 & 66.7 & 60 & 33.3 \\
\hline \multirow{3}{*}{7} & \multirow{3}{*}{ Kurmukchay-Ilisu } & 1959 & 3.44 & 109 & 60.1 & 55.1 & 48.9 & 44.9 \\
\hline & & 1970 & 5.06 & 160 & 97.3 & 60.8 & 62.7 & 39.2 \\
\hline & & 1965 & 7.29 & 230 & 108 & 47.0 & 122 & 53.0 \\
\hline \multirow{3}{*}{8} & \multirow{3}{*}{ Talachay-Zagatala } & 1966 & 2.89 & 91.2 & 56.6 & 62.1 & 34.6 & 37.9 \\
\hline & & 1967 & 3.82 & 121 & 63.7 & 52.6 & 57.3 & 47.4 \\
\hline & & 1963 & 6.39 & 202 & 94.4 & 46.7 & 108 & 53.3 \\
\hline
\end{tabular}

recurring dry years, absolute and relative amounts of underground flow are small due to its sharp reduction. For example, the average annual water discharge for 2010 and 1961 was 4.93, 4.92 and 3.88 for Garachay, Balakenchay and Chukhadurmaz rivers respectively. In wet year 2010, Balakanchay river's groundwater recharge coefficient was $74.5 \%$, while in dry year 1961 it was $23.7 \%$. These figures were 88.1 and $29.2 \%$ for Chukhadurmaz river and $76.8 \%$ and $56.0 \%$ for Garachay river, respectively.

In general, the methods of hydrographs separation (HS) by feeding sources are divided into three groups (Okello et al., 2018):
1. Graphical methods - The engineering methods, taking into account the seasonal dynamics of flow, were widely used in 1930-60s.

2. Methods of solved tracers - have been used since the 1960 s to this day. The methods allow separating the various origin waters by their hydrochemical features.

3. Method of natural isotope tracers - has been applied since the 1970s. At present, this is considered to be the most modern method, which allows determining the "age of water", i.e. whether the water is "new" (e.g., fresh rainfall water) or "old" (waters of melted snow or rain before the considered rainfall). 
The isotope method is based on the study of isotopic (tritium) composition of water (Ward and Robinson, 2000) and is considered to be more promising (Chizhova et al., 2016). Isotope method (tritium isotope) has been applied for about 50 years (Hubert et al., 1969). However, the ${ }^{18} \mathrm{O}$ isotope has also been used since the 1970s (Dincer et al., 1970). At present, the number of scientific studies devoted to HS via isotope method is more than 300 (Vasilchuk et al., 2016).

We should mention that an underground flow (UF) chart of the Earth has been drawn up based on outcomes of river HS of UF (World map..., 1999).

It should be noted with regret that only graphical methods are used in Azerbaijan. So far, UF to the rivers of Azerbaijan have been assessed solely based on HS drawn up for a total of 4-7 typical water years. The calculated quantities for these years have been averaged, and distribution patterns of the UF throughout the area have been determined (Rustamov et al. 1969; Kashkai, 1973; Rustamov and Kashkai, 1978).

Such an approach is related to the fact that in practice, determination of surface and underground flows, as well as their proportions, in other words, the vertical structure of annual flow takes much time, mainly when the calculations are performed massively and information on daily water discharge is not available in electronic format. It is not possible to estimate the variability of both underground and surface flow over a multi-year period, according to data of only 4-7 years.

Taking this into account, the possibilities of using the minimum monthly water discharge data provided by the State Water Cadastre reports to determine the annual rates of UF to rivers have been investigated. This approach is genetically justified, because during periods of minimum flows the rivers feed mainly on groundwater (Zektser (ed.), 2007; Kozek, 2018; Kaznowska et al., 2018). The study was conducted in 4 options, and in each option, the values obtained based on the minimum monthly water discharge of UF have been compared to values (base values) obtained based on HS (8 rivers and 24 hydrographs) drawn up for typical years (3 years low, medium and high-water years).

In the first option, the possibility of using data on baseflow, which is a regular part of overall streamflow, has been studied instead of UF. Thus, baseflow and UF are very similar in their origin - namely UF constitutes a significant part of baseflow. This is explained by the fact that the annual distribution of flow is marginally dependent on the water level of the year. For example, the average multi-year rate of the relative value of Gusarchay baseflow is 0.68 , which is also 0.68 during a wet year $(P=25 \%), 0.61$ during a medium year $(P=$ $50 \%)$, and 0.67 during a dry year $(P=75 \%)$. For Damarjig River these figures are $0.81,0.85,0.78$ and 0.83 respectively (Imanov, 2000).

It was determined that the baseflow index is $0.37-$ -0.81 , whereas the groundwater recharge coefficient varies, ranging from 0.37 to 0.61 . The difference between two different coefficients is always positive, and it ranges from 0.00 to 0.40 , and is 0.25 on average. This means that $25 \%$ of the base flow is generated by surface water. Therefore, it is not correct to use baseflows instead of UF in the studies (Aliyeva, 2018).

In the following three options, the calculations were performed only based on the average monthly minimum winter and summer-autumn water discharge.

In the second option, the UF was assessed based on the average monthly minimum winter water discharge. The outcomes of the comparative analysis show that the average value of positive and negative differences of UF rates calculated via the two different methods varies between $-45.5 \%$ and $+63.7 \%$. The difference for 22 out of 24 hydrographs is negative, i.e. the rates of UF calculated based on average monthly minimum winter water discharge are lower than its base values. This is explained by the nature of river regime, and primarily by the nature of the annual distribution of streamflow: in most years, the minimum winter water discharge is several times lower than the minimum summer-autumn water discharge.

In the third option, the calculations were carried out based on the minimum average monthly water discharge. It was determined that the differences in UF rates calculated via the two different methods have slightly decreased: $-38.8 \%$ and $+48.8 \%$. However, there are also errors equal to -90.7 and $+95.0 \%$. These differences are not acceptable for practical calculations. It should be noted that, in this option, the number of positive and negative differences is distributed relatively equally -14 and 10 , respectively.

In the fourth option, the assessment was carried out by taking into account both average monthly minimum winter and summer-autumn water discharges 
based on their numerical average. The outcomes of the analysis show that the average value of positive and negative differences of UF rates calculated via two different methods varies between $33.4 \%$ and $+14.3 \%$. The mean error of the calculation is $\pm 23.8 \%$. The number of positive and negative differences is identical -12 in both cases.

Thus, in the fourth option, i.e. when the annual average of UF is calculated based on the numerical average of the average monthly minimum winter and summer-autumn discharge, the value of error is minimal compared to the remaining three methods. However, the values of errors are relatively high in three rivers - Valvalachay, Shabranchay and Girdimanchay both, during low and high-water years. Therefore, the amount of UF for the 1961s and 2000s, distinguished by extremely dry and extremely wet years, was calculated.

It was found out that the average of positive and negative differences of 1961, a dry year, is in the range of $-13.2 \%$ and $+18.3 \%$. The mean error of the calculation is $\pm 15.9 \%$. The number of positive ( 7 rivers) and negative (6 rivers) differences is almost identical. The figures for 2010 , an extremely wet year, are $-21.3 \%$, $+32.2 \%, \pm 28.1 \%$ ( 5 rivers) and (3 rivers) respectively.

To conclude, annual values of UF to the rivers of the Greater Caucasus can be determined by a numerical average of the average monthly minimum winter and summer-autumn water discharges. It should be noted that this approach partly takes into account seasonal dynamics of UF in most of the year - winter and summer-autumn, which last 7-9 months in general. The main drawback of this calculation method is that the UF dynamics (determination of the UF maximum and date of its observation) during the flood (3-5 months) are not taken into account.

\section{CONCLUSIONS}

It has been established that the UFC, which is a quantitative indication of the feeding of groundwaters by infiltration in the Greater Caucasus region, is affected by the landscape and soil types of the area, and by the average altitude of catchment area relative to the geological structure. The correlation coefficients of interaction between the UFC and the average altitude of the catchment area vary from 0.79 to 0.96 . As the average altitude increases, the UFC also increases. Thus, the average altitude of the catchment area is an integral indicator of the physical and geographical factors affecting the recharge of groundwaters by infiltration.

The differences between the average multi-year values of the Greater Caucasus rivers' baseflow coefficient and GFC is about 0.25 . This means that $25 \%$ of the baseflow is generated by surface waters. This is a significant figure, and therefore it is not appropriate to use baseflows instead of UF when studying the vertical structure of the annual flow.

In the studied area, the UFC for the rivers is on average: $63.85 \%$ in dry years, $55.2 \%$ in medium years, and $59.5 \%$ in wet years. The results of this evaluation once again confirm that the role of groundwater in feeding rivers increases during dry years. However, this regularity is violated during dry and wet years.

In the north-eastern slope of the Greater Caucasus, the UFC increases along with the increase in the average altitude of the catchment areas. However, this increase only continues up to the altitude of 2,600 m, above which the UFC begins to decrease in higher altitudes. This can be explained by the long-term winter period in the high mountain regions and by the freezing of the soil layer and, as a consequence, by the decline in groundwater flow to the rivers.

The calculation of annual UF to the rivers of the Greater Caucasus can be performed based on the numerical average of the average monthly minimum winter and summer-autumn water discharges. The mean error of the calculation is $\pm 23.8 \%$. The calculation errors for dry years and for wet years can be considered acceptable for practical use. However, this calculation method does not take into account the dynamics of UF during flood periods.

\section{REFERENCES}

Abrahams, A.D., Parsons, A.J., Wainwright J. (1994). Resistance to overland flow on semiarid grassland and shrubland hillslopes, Walnut Gulch, southern Arizona, F. Hydrol., 156, 431-446

Aliyeva, I.S. (2018). The analysis of the relationship between the underground and base flows of the Greater Caucasus rivers. Water Problems, Science and Technology,1(11), 21-27.

Anderson, J.M., Spencer, T. (1991). Carbon, nutrient and water balances of tropical rain forest ecosystems subject to disturbance, MAB Digest 7, Paris: UNESCO. 
Bonell, M., Hendriks, M.R., Imeson, A.C., Hazelhoff L. (1984). The generation of storm runoff in a forested clayey drainage basin in Luxembourg, F.Hydrol., 71, 53-77.

Chizhova, Yu.N., Rets, E.P., Vasilchuk, Yu.K., Tokarev, I.V., Budandzeva, N.A., Kireeva M.B. (2016). Two approaches the computational expansion of the hydrograph of the glacier-fed rivers with the help of isotopic methods. Ice and snow, 56, 20, 161-168.

Doganovsky, A.M., Malinin, V.N. (2004). Hydrosphere of the Earth. Gidrometeoizdat: St. Petersburg.

Dincer, T., Payne, B.R., Flowkowski, T., Martinec, J. Tongiorgi, E. (1970). Snowmelt runoff from measurements of Tritium and Oxygen-18. Water Resour. Res., 6, 110-124.

Dzhamalov, R.G., Zektser, İ.S. (ed.) (1999). World Map of hydrogeological conditions and groundwater flow. Scale 1: 10000000 USA.

Gashgai, R.M. (1973). The water balance of the Greater Caucasus within the Azerbaijan SSR. Baku, Elm.

Grinevsky, S.O., Novoselova, M.V. (2010). Patterns of formation infiltration feeding groundwater. Water Resources, 37, 6, 1-12.

Hewlett, I.D. (1961). Soil moisture as a source of baseflowfrom steep mountain watersheds, Southeastern Forest Experiment Station, Paper 132, Ashville, N.C.: US Forest Service.

Hewlett, I.D., Hibbert, A.R. (1967). Factors affecting the response of small watersheds to precipitation in humid areas. In: Forest Hydrology, W.E. Sopper and H.W. Lull (eds.), Oxford: Pergamon, 275-290.

Horton, R. E. (1933). The role of infiltration in the hydrologic cycle. Trans. AGU, 14, 446-460.

Hubert, P., Marin, E., Meybeck, M., Olive, P. Siwertz, E. (1969). Aspects Hydrologique, Geochimique et Sedimentologique de la Crue Exceptionnelle de la Dranse du, Chablais du 22 Septembre 1968 Archives des Sci. (Geneve). 22(3), 581-604.

Hydrological role of forest geosystems. (1989). Novosibirsk: Science.

Imanov, F.A. (2000). Minimum flow of the rivers of the Caucasus. Nafta-press: Baku.

Imanov, F.A., Alakbarov, A.B. (2014). Mutual interaction of ground water and surface water in the context of groundwater flow to surface in Azerbaijan. 2nd Caspian International Aqua Technologies. Conference materials. Azerbaijan, Baku. Baku: Mutarjim, 69-74.

Imanov, F.A., Khalilov, S.G., Hasanova, N.I. (2015). Conditions for the formation of floods in the lower reaches of the Kura River in 2010. News of Baku University, a series of natural sciences. 4, 126-134.
Jungerius, P.D. (1985). Soils and geomorphology, Catena, Suppl. 6, 18.

Jury, W.A. (1982). Simulation of solute transport using a transfer function model, WRR, 18: 363-368.

Kalacheva, E.G. (2008). Application of the water balance method to study the feeding conditions of groundwater in the northern part of Paramushir Island, Kuril Islands. News KRAUNZ, a series of earth sciences, 12, 87-94.

Kaznowska, E., Hejduk, A., Kempinski, Ch. (2018). The Vistula River low flow in Warsaw in the 21st century. Acta Sci.Pol. Form. Cir., 17.1: 29-38. http://dx.doi. org/10.15576/ASP.FC/2018.17.1.29

Kozek, M. (2018). Spatial variability of low-flows in the upper Warta River catchment. Acta Sci. Pol. Form. Cir., 17.3: 67-76. http://dx.doi.org/10.15576/ASP.FC/2018.17.3.67

Okello, A.S., Masih, I., Uhlenbrook, S., Jewitt, G., Zaag Pieter Van., (2018). Improved Process Representation in the Simulation of the Hydrology of a Meso-Scale Semi-Arid Catchment, Water,10, 11, (1549), 10.3390/ w10111549,

Rawitz, E., Engman, E.T., Cline, G.D. (1970). Use of the mass balance method for examining the role of soils in controlling watershed performance, WRR, 6, 1115-1123.

Rustamov, S.G., Gashgai, R.M. (1978). Water balance of Azerbaijan SSR. Baku.

Rustamov, S.G., Jafarov, B.S., Gadzhibekov, N.G. (1969). Water balance of the river basins in Lesser Caucasus. Elm: Baku.

Shiklomanov, I.A. (ed.). (2008). Water resources of Russia and their use. St. Petersburg: State Hydrological Institute.

Shiklomanov, I.A., Podda, J. (ed.). (2003). Worla Water Resoursesat the Beginning of the 21st Century. - UNESCO, Cambridje Univ. Press.

Sokolov, B.L., Sarkisyan, V.O. (1981). Underground feeding of mountain rivers. L.: Gidrometeoizdat.

Subbotin, A.I. (1966). Melt and rainwater runoff (according to experimental data). M.: Gidrometeoizdat.

Vasilchuk, Yu. K., Retz, E.P., Chizhova, Yu.N., Tokarev, I.V., Frolova, N.L., Budantseva, N.A., Kireeva, M.B. Loshakova, N.A. (2016). Dismemberment of the hydrograph of the Dzhankuat River, Central Caucasus, using isotope methods. Water resources, 43, 579-594.

Vinogradov, Yu.B., Vinogradova, T.A. (2008). Modern problems of hydrology. Moscow, Ed. Center Academy.

Ward, R.C., Robinson, M. (2000). Principles of Hydrology, McGraw-Hill: London.

Zektser, I.S. (ed.) (2007). Groundwater of the World: resources, use, prognoses. Water Problems Institute of RAS. Nauka: Moscow. 


\section{BADANIE PODZIEMNEGO PRZEPLYWU RZEK WIELKIEGO KAUKAZU W AZERBEJDŻANIE}

\section{ABSTRAKT}

\section{Cel badania}

Zastosowanie wód podziemnych $\mathrm{w}$ celu zaopatrzenia w wodę pitną wzrosło $\mathrm{w}$ ostatnich latach $\mathrm{z}$ powodu intensywnego zanieczyszczenia lokalnych i transgranicznych rzek w regionie Wielkiego Kaukazu w Azerbejdżanie. Oprócz stosunkowo głębokich wód gruntowych do tego celu szeroko stosuje się również podziemny przepływ rzek. Celem niniejszych badań jest analiza stanu podziemnego przepływu rzek w regionie oraz określenie ich rozmieszczenia terytorialnego.

\section{Materiał i metody}

Zbadano możliwości wykorzystania minimalnego miesięcznego odpływu wody w celu ustalenia rocznych prędkości przepływu podziemnego do rzek. Badanie przeprowadzono w 4 wariantach, a dla każdego wariantu wartości uzyskane na podstawie minimalnego miesięcznego odpływu podziemnego porównano z wartościami uzyskanymi na podstawie rozdziału hydrogramu odpływu sporządzonego dla typowych lat.

\section{Wyniki i wnioski}

Na współczynnik podziemnego przepływu, który jest ilościowym wskaźnikiem zasilania wód gruntowych przez infiltrację w regionie Wielkiego Kaukazu, mają wpływ czynniki fizyczne i geograficzne. Wraz ze wzrostem średniej wysokości rośnie również współczynnik podziemnego przepływu. Zatem średnia wysokość zlewni jest integralnym wskaźnikiem czynników fizycznych i geograficznych wpływających na zasilanie wód gruntowych przez infiltrację. Różnica między średnimi wieloletnimi wartościami współczynnika przepływu podstawowego rzek Wielkiego Kaukazu, a współczynnikiem zasilania wodami gruntowymi wynosi około 0,25 . Na badanym obszarze współczynnik zasilania wodami gruntowymi dla badanych rzek wynosi średnio $63,85 \%$ w latach suchych, $55,2 \%$ w latach średnich i 59,5\% w latach mokrych.

Słowa kluczowe: infiltracja, wody podziemne, Wielki Kaukaz, rozdział hydrogramu odpływu, przepływ minimalny 